\title{
Absorption and Metabolism of Dermally Applied Phenothrin in Rats
}

\author{
Hideo Kaneko, Hideo Ohkawa and Junshi Miyamoto \\ Research Department, Pesticides Division, Sumitomo Chemical Co., Ltd., \\ Takarazuka, Hyogo 665, Japan
}

(Received September 26, 1980)

\begin{abstract}
In dermal treatment of male rats with dust and emulsifiable concentrate (E.C.) of both ${ }^{14} \mathrm{C}-[(+)-$ trans $]$ - and ${ }^{14} \mathrm{C}-[(+)-c i s]$-phenothrin at the rates of 0.2 and $2 \mathrm{mg} / \mathrm{rat}$, the ${ }^{14} \mathrm{C}$ absorption into the body was estimated to be 3-7\% of the initial dose with dust and $8-17 \%$ with E.C. The absorption rate of ${ }^{14} \mathrm{C}$ was $4-5$ times faster with E.C. than with dust, whereas the half-life of ${ }^{14} \mathrm{C}$ in the blood was $2-3$ times longer with E.C. than with dust. The radiocarbon absorbed through the skin was almost completely eliminated into urine and feces 6 days after treatment. The ${ }^{14} \mathrm{C}$ tissue residues were very low, except on the treated portion of skin. With single oral administration of both isomers of ${ }^{14} C$-phenothrin, roughly $96 \%$ of the dose was recovered into the excreta during the following 6 days; a larger amount of ${ }^{14} \mathrm{C}$ was excreted into the feces with the $[(+)-c i s]$-isomer and into the urine with the $[(+)-$ trans]-isomer. Nearly the same metabolites were obtained in oral and dermal treatments with either the $[(+)-$ trans $]$ or the $[(+)-c i s]$-isomer, although the nature and amount of metabolites differed. The major metabolites from the $[(+)$-trans]-isomer were 3-phenoxybenzoic acid (free and glycine conjugate) and 3-(4'-hydroxyphenoxy)benzoic acid (free and sulfate), although small amounts of ester metabolites were also obtained. The cis-isomer afforded larger amounts of ester metabolites which resulted from oxidation at the $4^{\prime}$-position of the alcohol moiety, at the trans and cis methyl of the isobutenyl group, at the trans methyl of the gem-dimethyl group of the acid moiety and at combinations of these oxidations; the amount of the ester-cleaved metabolites was about one-fifth of those from the trans-isomer. It is likely that in dermal treatment, once entering the blood stream through the skin, the phenothrin isomers are metabolized in a manner similar to oral administration.
\end{abstract}

\section{INTRODUCTION}

The pyrethroid insecticide, phenothrin [3phenoxybenzyl (土)-trans, cis-chrysanthemate] is very effective in controlling insect pests of man and livestock. This compound has very low mammalian toxicity, the single oral and dermal $\mathrm{LD}_{50}$ values for rats each being more than $10 \mathrm{~g} / \mathrm{kg}$. In oral administration to rats the $[(+)$-trans $]$-phenothrin was readily metabolized and the metabolites almost completely eliminated into the urine and feces. ${ }^{1)}$ The excreted metabolites resulted mainly from cleavage of the ester linkage, hydroxylation at the $4^{\prime}$-position of the alcohol moiety and conjugation of 3-phenoxybenzoic acid with glycine. On the other hand, hydrolysis of the ester linkage of the $[(+)-$ cis]-phenothrin occurred to a lesser extent than with the $[(+)$-trans $]$-isomer, ${ }^{1,2)}$ and the metabolism proceeded mainly through oxidation at several positions of both alcohol and acid moieties.

Recently it has been found that the dust formulation of a $8: 2$ mixture of $[(+)$-trans]and $[(+)-c i s]$-phenothrin(Sumithrin ${ }^{\circledR}$ ) is effective in lice control. Prior to practical use, it is essential to elucidate absorption and metabolism of the components in mammals through dermal application.

This report deals with absorption, distribution, tissue residues and metabolism of the 
$[(+)$-trans $]$ - and $[(+)$-cis $]$-isomers following dermal application to rats in comparison with oral administration.

\section{MATERIALS AND METHODS}

\section{1. ${ }^{14} \mathrm{C}$-Labeled Compounds}

${ }^{14} \mathrm{C}-[(+)$-trans $]-$ and ${ }^{14} \mathrm{C}-[(+)-c i s]$-phenothrin labeled at the benzyl methylene group of the alcohol moiety with a specific activity of $7.3 \mathrm{mCi} / \mathrm{mmol}$ were synthesized by Hazue et $a l .{ }^{3)}$ of the Institute for Biological Science, Sumitomo Chemical Co., Ltd., Takarazuka, Japan. Both ${ }^{14} \mathrm{C}$-preparations had a radiochemical purity of more than $99 \%$, as determined by thin-layer chromatography in $n$ hexane/acetone (4/1) and toluene.

\section{Spectroscopy}

Nuclear magnetic resonance spectra (NMR) were determined in deuteriochloroform using tetramethylsilane as an internal standard with a Hitachi model R-40 spectrometer at 90 $\mathrm{MHz}$. Infrared spectra (IR) were obtained on a Hitachi model 285 spectrometer as liquid thin-film on $\mathrm{NaCl}$ crystals or as a chloroform solution. Electron impact mass spectra (MS) were determined at 12 and $70 \mathrm{eV}$ with a Shimadzu-LKB 9000 mass spectrometer using a direct insertion probe.

\section{Thin-layer Chromatography (tlc)}

Tlc was conducted for both analysis and preparation of metabolites using precoated

Table 1 Tlc $R f$ values for phenothrin isomers and authentic standards and solvent systems used.

\begin{tabular}{|c|c|c|c|c|c|c|}
\hline \multirow{2}{*}{ Compound } & \multicolumn{6}{|c|}{$R f$ values in solvent systems } \\
\hline & $\mathrm{A}$ & $\mathrm{B}$ & $\mathrm{C}$ & $\mathrm{D}$ & $\mathrm{E}$ & $\mathrm{F}$ \\
\hline PBalc & 0.40 & 0.45 & & & & 0.24 \\
\hline PBacid & 0.57 & 0.55 & & & & 0.41 \\
\hline PBacid-Me & 0.70 & 0.79 & & & & 0.56 \\
\hline $2^{\prime}-\mathrm{OCH}_{3}-\mathrm{PBacid}-\mathrm{Me}$ & 0.62 & 0.75 & & & & 0.43 \\
\hline $2^{\prime}-\mathrm{OH}-\mathrm{PBacid}$ & 0.32 & 0.34 & & & & 0.19 \\
\hline $4^{\prime}-\mathrm{OCH}_{3}-\mathrm{PBacid}-\mathrm{Me}$ & 0.66 & 0.76 & & & & 0.45 \\
\hline $4^{\prime}-\mathrm{OH}-\mathrm{PBacid}$ & 0.21 & 0.25 & & & & 0.10 \\
\hline PBacid-glycine & 0.04 & 0.06 & & & & 0.03 \\
\hline PBacid-glycine-Me & 0.19 & 0.26 & & & & 0.12 \\
\hline$t$-Phen. & 0.84 & 0.88 & 0.59 & 0.60 & 0.65 & 0.76 \\
\hline$\omega t$-alc- $t$-Phen. $(\mathrm{O})$ & 0.32 & 0.40 & 0.17 & 0.23 & 0.54 & 0.27 \\
\hline$\omega t$-acid-Me-t-Phen. (P) & 0.64 & 0.78 & 0.43 & 0.50 & 0.65 & 0.50 \\
\hline $4^{\prime}-\mathrm{OCH}_{3}-t-$ Phen. & 0.77 & 0.83 & 0.49 & 0.54 & 0.65 & 0.50 \\
\hline$c$-Phen. & 0.86 & 0.88 & 0.59 & 0.60 & 0.67 & 0.76 \\
\hline $4^{\prime}-\mathrm{OCH}_{3}-c-\mathrm{Phen}$. & 0.76 & 0.83 & 0.49 & 0.54 & 0.65 & 0.63 \\
\hline$\omega t$-acid-Me-c-Phen. (C) & 0.61 & 0.78 & 0.42 & 0.49 & 0.64 & 0.49 \\
\hline$\omega t$-alc-c-Phen. (A) & 0.33 & 0.38 & 0.18 & 0.26 & 0.55 & 0.28 \\
\hline$\omega c-$ alc-c-Phen. $(\mathrm{G})$ & 0.36 & 0.42 & 0.18 & 0.26 & 0.55 & 0.28 \\
\hline $4^{\prime}-\mathrm{OHC}_{3}-\omega c$-alc-c-Phen. (H) & 0.33 & 0.37 & 0.15 & 0.21 & 0.54 & 0.24 \\
\hline $4^{\prime}-\mathrm{OCH}_{3}-\omega t$-alc- $-c-$ Phen. (B) & 0.30 & 0.33 & 0.14 & 0.21 & 0.54 & 0.24 \\
\hline $4^{\prime}-\mathrm{OCH}_{3}-\omega c$-acid-Me-c-Phen. (I) & 0.66 & 0.79 & 0.43 & 0.49 & 0.63 & 0.50 \\
\hline $4^{\prime}-\mathrm{OCH}_{3}-\omega t$-acid-Me-c-Phen. (D) & 0.58 & 0.75 & 0.37 & 0.44 & 0.63 & 0.42 \\
\hline$\omega t$-acid-Me-2-OH $(t)-c-$ Phen. (E) & 0.21 & 0.26 & 0.11 & 0.17 & 0.52 & 0.15 \\
\hline $4^{\prime}-\mathrm{OH}-\omega t$-acid-Me-2-OH $(t)-c-$ Phen. $(\mathrm{F})$ & 0.05 & 0.10 & 0.02 & 0.06 & 0.45 & 0.03 \\
\hline
\end{tabular}

Solvent systems :

A) $n$-hexane/toluene/acetic acid $=3 / 15 / 2$, two developments,

B) benzene saturated with formic acid/diethylether $=10 / 3$, two developments,

C) $n$-hexane/chloroform/acetone $=4 / 1 / 1$,

D) $n$-hexane/diethylether $=1 / 3$,

E) ethylacetate/diethylether $=3 / 1$,

F) $n$-hexane/chroloform/acetic acid $=4 / 1 / 1$,

G) $n$-butanol/acetic acid/water $=6 / 1 / 1$. 
silica gel $60 \mathrm{~F}_{254}$ chromatoplates $(20 \times 20 \mathrm{~cm}$, $0.25 \mathrm{~mm}$ thickness, E. Merck). $R f$ values for phenothrin isomers and related authentic standards, and solvent systems used are listed in Table 1. The radioactive spots on $t l c$ plates were localized by placing X-ray films (SB-5, Kodak) on the developed $t l c$ plates at $4-8^{\circ} \mathrm{C}$ for about 1 week, and then processing the exposed films. The unlabeled authentic standards on tlc plates were detected by quenching of gel fluorescence under UV light.

\section{Designation of Compounds}

The following abbreviations were used: $t$ and $c$ for $(+)$-trans and $(+)$-cis, respectively; $\omega t$ and $\omega c$ for the trans and the cis methyl positions of the isobutenyl group relative to the double bond, respectively; $2-\mathrm{OH}(t)$ for the trans hydroxy group at the gem-dimethyl group attached to the cyclopropane ring relative to carbonyl group; $4^{\prime}-\mathrm{OH}$ and $4^{\prime}-\mathrm{OCH}_{3}$ for hydroxy and methoxy groups at the $4^{\prime}-$ position of the alcohol moiety, respectively.

\section{Chemicals}

$\omega t$-alc- $t$ - and $\omega c-$ alc- $-c-$ Phenothrin and $\omega t-$ acid-Me- $t$-phenothrin were prepared according to the methods of Matsui et al. ${ }^{4}$ ) The $\mathrm{nmr}$, ir and ms data for the three products were as follows; $\omega t$-alc- $t$-phenothrin: NMR $\delta$ (ppm), $1.15(\mathrm{~s}, 3 \mathrm{H}), 1.26(\mathrm{~s}, 3 \mathrm{H}), 1.50(\mathrm{~d}$, $1 \mathrm{H}), 1.73(\mathrm{~s}, 3 \mathrm{H}), 2.13(\mathrm{dd}, 1 \mathrm{H}), 4.01$ (s, $2 \mathrm{H}), 5.10(\mathrm{~s}, 2 \mathrm{H}), 5.20(\mathrm{~m}, 1 \mathrm{H}), 6.90-7.50$ $(\mathrm{m}, 9 \mathrm{H})$; IR $\nu_{\max }^{\text {direct }}\left(\mathrm{cm}^{-1}\right), 3,200-3,700(\mathrm{OH})$, 1,720 (CO), 1,585 and 1,485 (aromatic ring); ms $(m / e), 366\left(\mathrm{M}^{+}\right), 183$ (base peak): $\omega t$-alc$c$-phenothrin: NMR $\delta$ (ppm), $1.22(\mathrm{~s}, 3 \mathrm{H}), 1.25$ (s, $3 \mathrm{H}), 1.75(\mathrm{~s}, 3 \mathrm{H}), 1.50-2.10(\mathrm{~m}, 2 \mathrm{H}), 4.03$ (s, $2 \mathrm{H}), 5.08$ (s, $2 \mathrm{H}), 5.70(\mathrm{~m}, 1 \mathrm{H}), 6.90-7.50$ $(\mathrm{m}, 9 \mathrm{H})$; IR $\nu_{\max }^{\text {direct }}\left(\mathrm{cm}^{-1}\right), 3,200-3,700(\mathrm{OH})$, 1,720 (CO), 1,585 and 1,485 (aromatic ring); ms $(m / e), 366\left(\mathrm{M}^{+}\right), 183$ (base peak): $\omega t$-acidMe-t-phenothrin: NMR $\delta$ (ppm), $1.22(\mathrm{~s}, 3 \mathrm{H})$, $1.30(\mathrm{~s}, 3 \mathrm{H}), 1.78(\mathrm{~d}, 1 \mathrm{H}), 1.93(\mathrm{~s}, 3 \mathrm{H}), 2.20$ (dd, $1 \mathrm{H}), 3.73(\mathrm{~s}, 3 \mathrm{H}), 5.13(\mathrm{~s}, 2 \mathrm{H}), 6.50(\mathrm{~m}$, $1 \mathrm{H}), \quad 6.90-7.60(\mathrm{~m}, 9 \mathrm{H})$; IR $\nu_{\max }^{\text {direct }}\left(\mathrm{cm}^{-1}\right)$, $1,720,1,700$ (CO), 1,575 and 1,475 (aromatic ring); MS (m/e), $394\left(\mathrm{M}^{+}\right), 183$ (base peak).

The following unlabeled reference compounds were prepared as reported previously:5,6) 3-phenoxybenzyl alcohol (PBalc), 3- phenoxybenzoic acid (PBacid), methyl 3phenoxybenzoate (PBacid-Me), 3-(2'-hydroxyphenoxy)benzoic acid (2'-OH-PBacid), methyl 3-(2'-methoxyphenoxy)benzoate $\left(2^{\prime}-\right.$ $\left.\mathrm{OCH}_{3}-\mathrm{PBacid}-\mathrm{Me}\right)$, 3-(4'-hydroxyphenoxy)benzoic acid (4'-OH-PBacid), methyl 3-(4'methoxyphenoxy)benzoate $\left(4^{\prime}-\mathrm{OCH}_{3}-\mathrm{PBacid}-\right.$ $\mathrm{Me}), \quad N-3$-phenoxybenzoylglycine (PBacidglycine), methyl $N$-3-phenoxybenzoylglycine (PBacid-glycine-Me), 3-(4'-methoxyphenoxy)benzyl $(+)$-trans-chrysanthemate $\left(4^{\prime}-\mathrm{OCH}_{3}-\right.$ $t$-phenothrin), 3-(4'-methoxyphenoxy)benzyl $(+)$-cis-chrysanthemate $\quad\left(4^{\prime}-\mathrm{OCH}_{3}-c\right.$-phenothrin).

\section{Radioanalysis and Radioautography}

Liquid scintillation counting (lsc), combustion analysis, ${ }^{14} \mathrm{CO}_{2}$ determination, tlc radioautography and whole-body radioautography were conducted as reported previously.5)

\section{Treatment of Rats}

Sprague-Dawley male rats (6-7 weeks old, about $200 \mathrm{~g}$, Nihon Dobutsu Co., Osaka, Japan) were used in this study. In the case of dermal treatment, the back of the rat was clipped by an electric clipper 1 day before treatment. The clipped rats were individually fixed on a plastic stage which enabled collection of urine and feces separately. Then 0.2 and $2 \mathrm{mg}$ of ${ }^{14} \mathrm{C}-t$ - or ${ }^{14} \mathrm{C}-c$-phenothrin dissolved in $0.2 \mathrm{ml}$ of a mixture of xylene and Sorpol $3005 \mathrm{X}^{\circledR}(10 / 1, \mathrm{v} / \mathrm{v})$ [emulsifiable concentrate (E.C.)] was uniformly applied to 30 $\mathrm{cm}^{2}$ of the back of the rats using a pipette. For the dust formulation, $2 \mathrm{mg}$ of ${ }^{14} \mathrm{C}-t$ - or $c$-phenothrin was mixed with $2 \mathrm{mg}$ of Span $80^{\circledR}$ as a stabilizer and then with $500 \mathrm{mg}$ of a talc powder [dust formulation]. The dust formulation at 2 or $0.2 \mathrm{mg}$ of the active ingredient was wetted with distilled water and then spread on $30 \mathrm{~cm}^{2}$ of a lint patch. The cloth was fixed on the clipped back of the rat using a surgical tape. The treated area (30 $\mathrm{cm}^{2}$ ) accounted for approximately $10 \%$ of the total body surface. The dose $(0.2 \mathrm{mg} / \mathrm{rat})$ of ${ }^{14} \mathrm{C}-t$-phenothrin corresponded approximately to that of practical use $\left(0.6 \mu \mathrm{g}\right.$ Sumithrin ${ }^{\circledR} /$ $\mathrm{cm}^{2}$ ). Twenty four hours after treatment the lint was taken out, and the treated skin was gently rubbed three times with cotton wetted 
with $2 \%$ of a shampoo solution and then with distilled water to remove the remaining material. The rats were then individually placed in all-glass metabolism cages (Metabolica CO$2^{\circledR}$, Sugiyamagen Iriki, Tokyo) and their urine and feces collected for 5 successive days. The radiocarbon in the cotton was extracted with methanol. The mean recovery of the radiocarbon from the skin was $101 \%$ immediately after treatment with E.C. formulation of ${ }^{14} C-t$-phenothrin. Radioactive materials present in surgical tapes and lint patches were extracted three times with acetone and methanol with an ultrasonic washer. Aliquots of the extracted residues were subjected to combustion analysis.

For oral administration, ${ }^{14} \mathrm{C}-t-$ and $c-$ phenothrin were each suspended in $10 \%$ Tween 80 solution and administered to male rats at the rate of $2 \mathrm{mg} / \mathrm{rat}$ using a stomach tube. The treated rats were individually held in all-glass metabolism cages for 6 days to collect urine and feces. The expired air was not trapped, because the radiocarbon was almost completely recovered in the urine and feces, as reported previously. ${ }^{1)}$

Six days after oral and dermal treatments the rats were sacrificed and tissues, including skin of the treated area, were removed. Aliquots $(100-300 \mathrm{mg})$ of tissues were subjected to combustion analysis. The limit of ${ }^{14} \mathrm{C}$ detection in tissues was 0.006 to $0.008 \mathrm{ppm}$ phenothrin equivalents.

Blood samples were collected from the abdominal artery or optic vein at various intervals after treatment. One-fifth $\mathrm{ml}$ aliquots of blood were blotted on filter papers (i.d. 5.5 $\mathrm{cm})$ for combustion analysis.

\section{Analysis of Excreta}

For analysis of excreted metabolites, the 2-day pooled urine was lyophylized, the residue was dissolved in methanol and subjected to $t l c$. The 2-day pooled feces were extracted three times with methanol/water $(9 / 1, \mathrm{v} / \mathrm{v}, 5 \mathrm{ml} / \mathrm{g}$ feces) using a Waring blender. The combined extracts were concentrated in vacuo by rotary evaporator at $35-40^{\circ} \mathrm{C}$ and subjected to $t l c$. The concentrated methanol extracts of the feces after dermal treatments were dissolved in distilled water and then ex- tracted three times with ethylacetate after acidification to $\mathrm{pH} 2$. The concentrated ethylacetate layers were analyzed by $t l c$.

\section{Identification of Metabolites}

The metabolites were tentatively identified by $t l c$ cochromatography with appropriate authentic standards by two or more of the solvent systems listed in Table 1 . The methanol extract of feces was subjected to $t l c$ in solvent system A; methanol extracts from urine were subjected to $t l c$ in solvent system B. Then each of the metabolites detected on $t l c$ plates was extracted with methanol and subjected to $t l c$ cochromatography before and/ or after methylation with diazomethane. ${ }^{5)}$

For preparation of sufficient amounts of the ester metabolites, ${ }^{14} C-c-$ phenothrin was administered 6 times every other day to 30 male rats at the rate of $200 \mathrm{mg} / \mathrm{kg}$. The pooled feces were extracted as described above, and the concentrated methanol-water extracts were partitioned between $n$-hexane and acetonitrile. The acetonitrile layer was concentrated and subjected to column chromatography on silica gel (100-200 mesh, $1 \mathrm{~kg}$, Tokyo Kasei Co., Ltd., Tokyo) using the following sequence of solvents: benzene-diethyl ether $(9 / 1,4 l),(1 / 1$, $5 l)$, acetone $(2 l)$ and methanol $(3.5 l)$. Certain metabolites were methylated in ether with diazomethane at $0-4^{\circ} \mathrm{C}$ for $5 \mathrm{~min}$. After concentration of the reaction mixture in vacuo, methylation was repeated twice in the same manner. Methylation was also performed at room temperature overnight. The methylated products were purified by repeated preparative $t l c$ in the following solvent systems A, C, $\mathrm{D}, \mathrm{E}, \mathrm{F}, n$-hexane/acetone $(4 / 1$, or $7 / 3), n$ hexane/ethylacetate $(1 / 4)$, benzene/ethylacetate $(7 / 3)$, benzene and $n$-hexane/chloroform (4/1). The purified ester metabolites and their derivatives were subjected to spectroanalysis (NMR, IR, and MS).

After $t l c$ analysis of methanol extracts of urine and feces in solvent systems A or B, the fraction at the origin of $t l c$ plates was scraped out, the origin fraction was extracted with methanol and subsequently analyzed by $t l c$ in solvent system G. Individual conjugates extracted from the $t l c$ plates were subjected to enzyme hydrolysis, as reported 
previously. ${ }^{5)}$

\section{RESULTS}

\section{Balance Study}

When dust and E.C. formulations of both ${ }^{14} \mathrm{C}-t$ - and $c$-phenothrin were dermally administered to rats, the radiocarbon was excreted into the urine and feces to the extent of $8-17 \%$ with E.C. and $3-7 \%$ with dust 6 days after treatment. A larger amount of radiocarbon was recovered in the urine with the $t$-isomer and in the feces with the $c$ isomer. Approximately $78-94 \%$ of the dose was recovered from the treated portion. The total recovery of the radiocarbon was $89-98 \%$ of the initial dose with E.C. and dust formulations of both isomers.

With single oral administration of ${ }^{14} \mathrm{C}-t$ and $c$-phenothrin to male rats at the rate of $2 \mathrm{mg} / \mathrm{rat}$, the radiocarbon was rapidly eliminated into the urine and feces. The total recovery of the radiocarbon was approximately $96 \%$ for both isomers 6 days after administration (Table 2). With the $t$-isomer, $75 \%$ of the dose was excreted into the urine and $21 \%$ into the feces. In contrast, with the $c-$ isomer, $22 \%$ of the dose was eliminated into the urine and $74 \%$ into the feces.

\section{Whole-body Radioautography}

Whole-body radioautography was conducted with rats treated dermally with E.C. and dust of ${ }^{14} \mathrm{C}-t$-phenothrin. Radiocarbon was detect- ed only in the treated portion of the back and in the contents of the bladder and intestines $24 \mathrm{hr}$ after treatment, and was scarce in other tissues (Fig. 1). The radioactivity in the treated skin was apparently higher with E.C. than with dust. A trace amount of the radiocarbon $144 \mathrm{hr}$ after treatment was detected only in the treated portion of rat skin with both E.C. and dust.

\section{3. ${ }^{14} \mathrm{C}$ Tissue Residues}

The ${ }^{14} \mathrm{C}$ tissue residues 6 days after dermal and oral administration were generally very low with no significant difference between the two isomers except higher radioactivity in the treated skin portion (Table 3). The tissue residue levels were somewhat lower with dust than with E.C. With oral administration, the highest radioactivity was found in the fat with both isomers. Somewhat higher radioactivity was however detected in adrenal, skin and caecum with $t$-phenothrin, and sciatic nerve, caecum and intestine with $c$-phenothrin. The residues were very low in other tissues examined.

\section{4. ${ }^{14}$ C Levels in Blood}

The radiocarbon level in blood was measured at various intervals after dermal treatment of male rats with 0.2 and $2 \mathrm{mg} / \mathrm{rat}$ of dust and E.C. formulation of ${ }^{14} \mathrm{C}-t$-phenothrin (Fig. 2). The radiocarbon level reached the maximum 8 to $24 \mathrm{hr}$ after treatment and rapidly de-

Table 2 Radiocarbon recovered in the excreta (urine and feces), skin wash and lint patch 6 days after dermal and oral administration of ${ }^{14} \mathrm{C}-t$ - and ${ }^{14} \mathrm{C}-c$-phenothrin at the rate of 0.2 and $2 \mathrm{mg} / \mathrm{rat}$.

\begin{tabular}{|c|c|c|c|c|c|c|c|c|c|}
\hline \multirow{2}{*}{$\begin{array}{l}\text { Phenothrin } \\
\text { isomers }\end{array}$} & \multirow{2}{*}{$\begin{array}{l}\text { Route of } \\
\text { dose }\end{array}$} & \multirow{2}{*}{$\begin{array}{l}\text { Formula- } \\
\text { tion }\end{array}$} & \multirow{2}{*}{$\begin{array}{c}\text { Dose } \\
(\mathrm{mg} / \mathrm{rat})\end{array}$} & \multicolumn{6}{|c|}{$\%$ of dosed ${ }^{14} C$} \\
\hline & & & & Urine & Feces & $\begin{array}{l}\text { Urine+ } \\
\text { Feces }\end{array}$ & $\begin{array}{l}\text { Skin } \\
\text { wash }\end{array}$ & $\begin{array}{l}\text { Lint } \\
\text { patch }\end{array}$ & $\begin{array}{c}\text { Total } \\
\text { recovery }\end{array}$ \\
\hline$t$ & Dermal & E.C. & 0.2 & 8.7 & 2.2 & 10.9 & 85.3 & & 96.2 \\
\hline$t$ & Dermal & E.C. & 2 & 6.6 & 1.8 & 8.4 & 85.4 & & 93.8 \\
\hline$t$ & Dermal & Dust & 0.2 & 2.6 & 1.1 & 3.7 & 16.7 & 72.6 & 93.0 \\
\hline$t$ & Dermal & Dust & 2 & 2.8 & 0.6 & 3.4 & 20.4 & 65.6 & 89.4 \\
\hline$t$ & Oral & & 2 & 75.1 & 20.9 & & & & 96.0 \\
\hline$c$ & Dermal & E.C. & 0.2 & 4.5 & 12.3 & 16.8 & 80.8 & & 97.6 \\
\hline$c$ & Dermal & E.C. & 2 & 4.8 & 11.5 & 16.3 & 77.7 & & 94.0 \\
\hline$c$ & Dermal & Dust & 0.2 & 2.6 & 4.0 & 6.6 & 24.9 & 66.1 & 97.6 \\
\hline$c$ & Dermal & Dust & 2 & 1.5 & 3.0 & 4.5 & 17.0 & 76.6 & 98.1 \\
\hline$c$ & Oral & & 2 & 22.4 & 73.5 & & & & 95.9 \\
\hline
\end{tabular}

Data show the mean values of duplicate experiments. 
E.C. $(2 \mathrm{mg} / \mathrm{rat})$
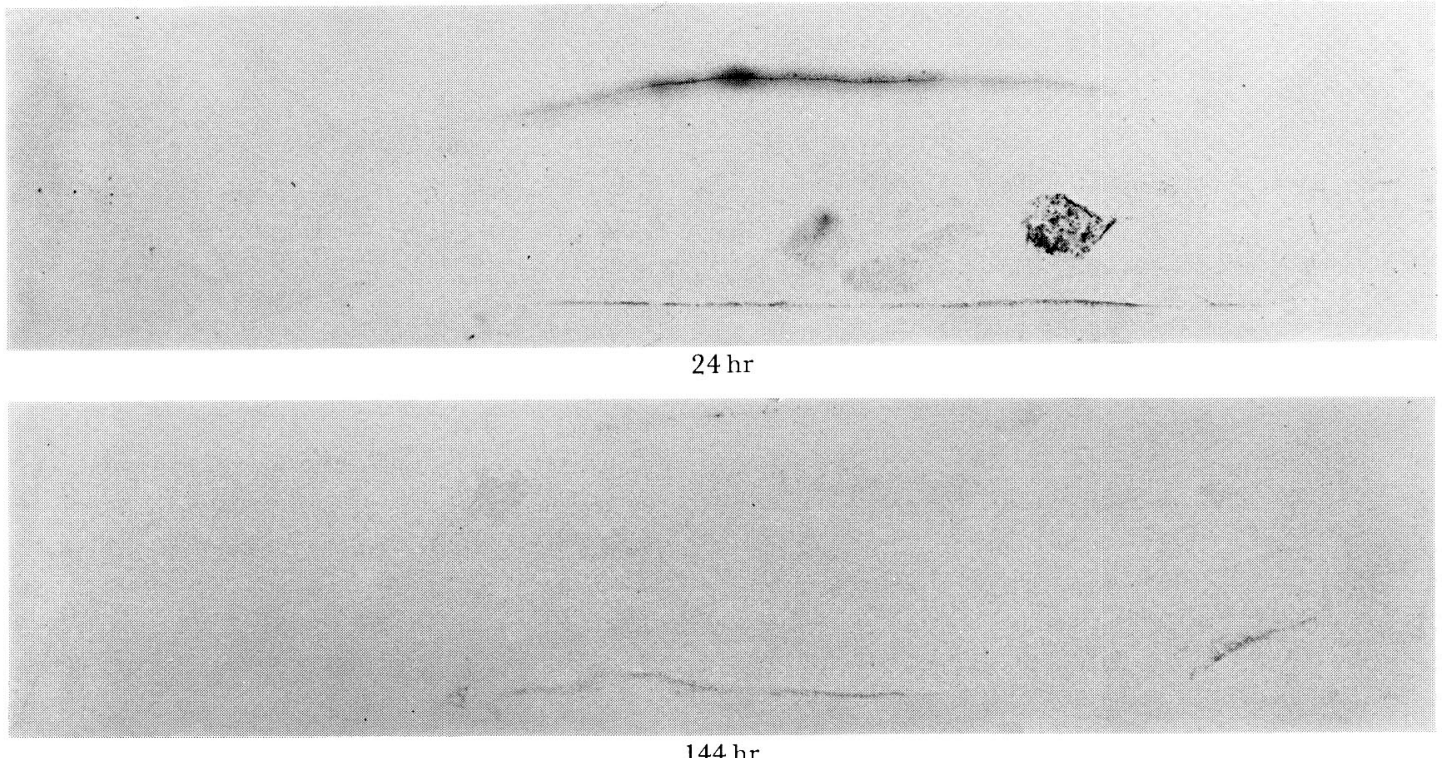

Dust (2 mg/rat)
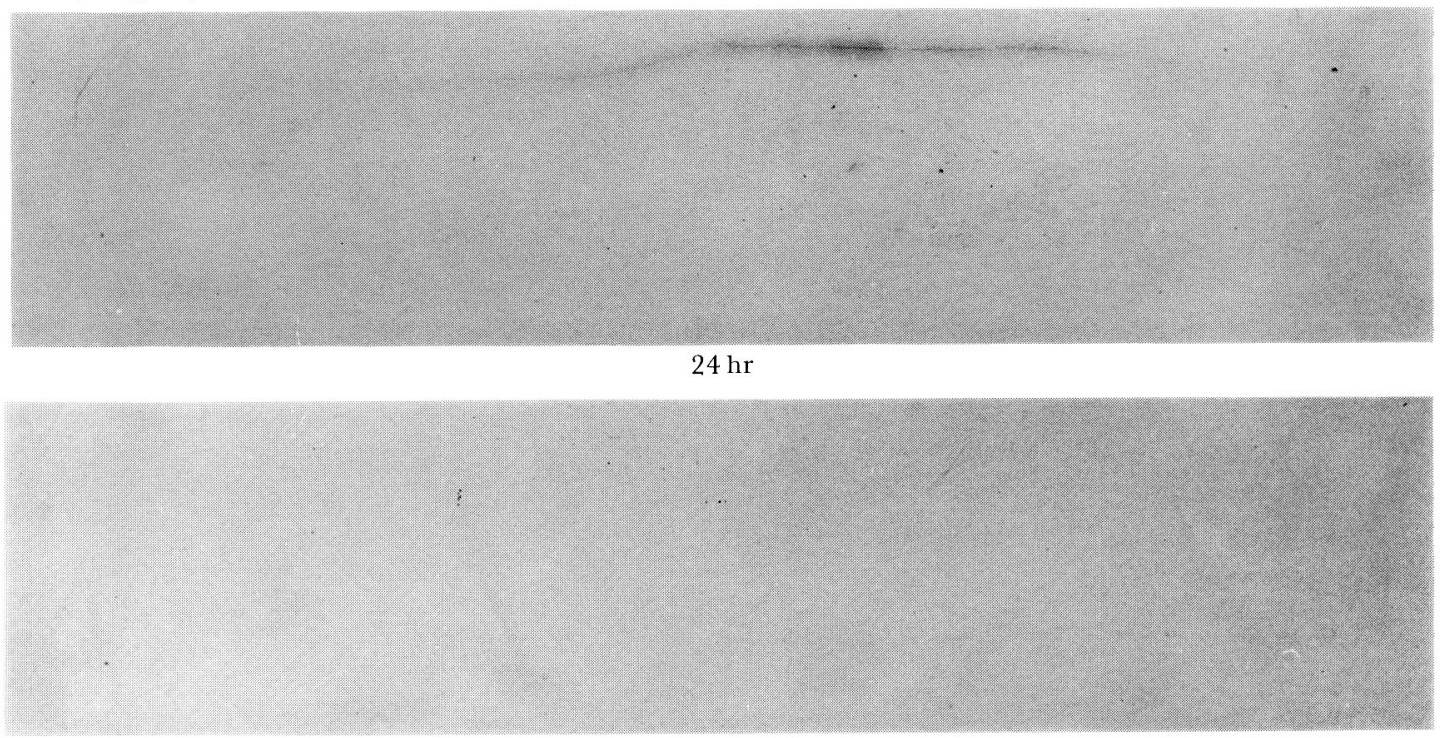

$144 \mathrm{hr}$

Fig. 1 Whole-body radioautograms showing ${ }^{14} \mathrm{C}$ distribution 24 and $144 \mathrm{hr}$ after dermal treatment of male rats with dust and E.C. formulations of ${ }^{14} \mathrm{C}-t$-phenothrin at $2 \mathrm{mg} /$ rat.

creased thereafter. The rate constant for ${ }^{14} \mathrm{C}$ absorption and half-life of ${ }^{14} \mathrm{C}$ in blood were calculated according to the method of leastsquares. The results are shown in Table 4 . With E.C. formulation, the absorption rate constant was 4-5 times larger, and the half- life of ${ }^{14} \mathrm{C}$ was $2-3$ times longer, as compared with the dust. $t$-Phenothrin was detected to the extent of $0.02-0.03 \mathrm{ppm}$ only $8 \mathrm{hr}$ after dermal treatment with $2 \mathrm{mg} /$ rat of two formulations, and was not detected at other measurements. 


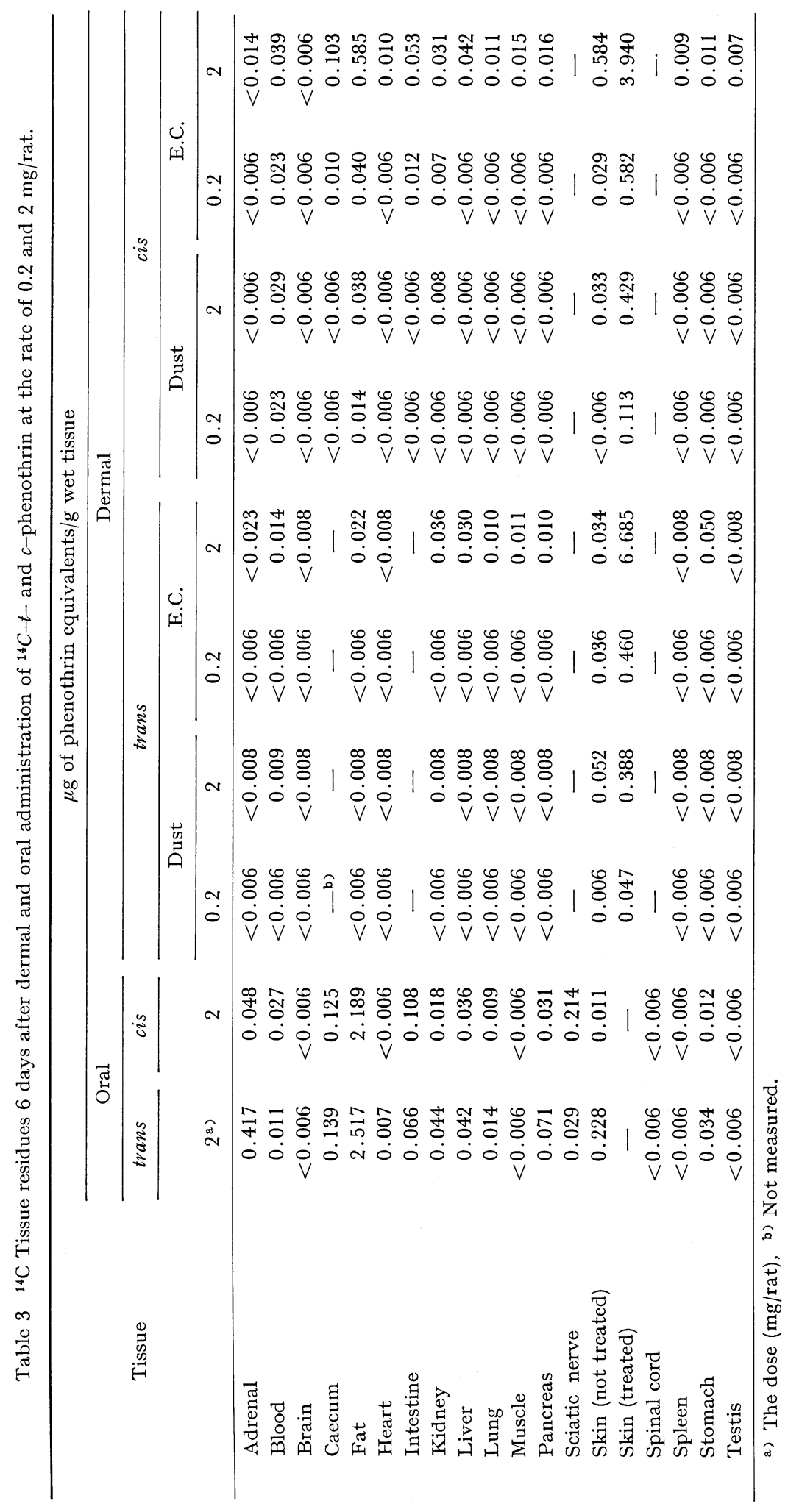




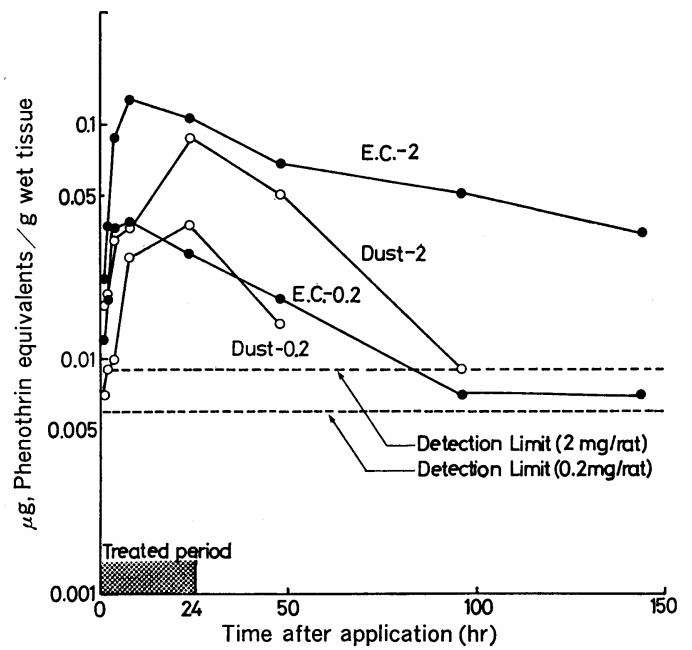

Fig. 2 The ${ }^{14} \mathrm{C}$ level in blood after dermal treatment of male rats with dust and E.C. formulation of $t$-phenothrin.

๑: E.C. $-2,2 \mathrm{mg} / \mathrm{rat}$ - E.C. $-0.2,0.2 \mathrm{mg} / \mathrm{rat}$,

$\bigcirc$ : Dust-2, $2 \mathrm{mg} / \mathrm{rat}, \mathrm{O}$ : Dust-0.2, $0.2 \mathrm{mg} / \mathrm{rat}$.

Table 4 The absorption rate constant and halflife of ${ }^{14} \mathrm{C}$ in blood in dermal treatment of male rats with dust and E.C. formulations of ${ }^{14} \mathrm{C}-t$-phenothrin.

\begin{tabular}{|c|c|c|c|}
\hline $\begin{array}{l}\text { Formula- } \\
\text { tion }\end{array}$ & $\begin{array}{c}\text { Dose } \\
(\mathrm{mg} / \mathrm{rat})\end{array}$ & $\begin{array}{l}\text { Absorption } \\
\text { rate con- } \\
\text { stant }\left(\mathrm{hr}^{-1}\right)^{\mathrm{a})}\end{array}$ & $\begin{array}{l}\text { Half- } \\
\left.\text { life }{ }^{\mathrm{b}}\right) \\
(\mathrm{hr})\end{array}$ \\
\hline \multirow[t]{2}{*}{ E.C. } & 0.2 & 0.363 & 53 \\
\hline & 2 & 0.238 & 74 \\
\hline \multirow[t]{2}{*}{ Dust } & 0.2 & 0.068 & 24 \\
\hline & 2 & 0.067 & 22 \\
\hline
\end{tabular}

a) $k=0.693 / T_{1}, T_{1}$ : time required for doubling of radioactivity,

b) $T_{2}$ : time required for halving of radioactivity.

\section{Identification of Metabolites}

The tlc patterns of urinary and fecal metabolites were similar in oral and dermal treatments, and in dust and E.C. formulations. Therefore, metabolite identification was mainly conducted with urinary and fecal metabolites of the rats treated orally. The urinary metabolites derived from both $t$ and $c$-isomers were well resolved by $t l c$ in solvent system B. ${ }^{5)}$ Among the detected metabolites, PBacid, 4'-OH-PBacid and PBacid-glycine were identified by $t l c$ cochromatography with the authentic standards.
On enzyme hydrolysis of each of the polar metabolites by $\beta$-glucuronidase and arysulfatase, PBacid, 4'-OH-PBacid and 2'-OHPBacid were released as aglycones, indicating the presence of sulfuric acid and glucuronic acid conjugates of PBacid, 2'-OH-PBacid and $4^{\prime}-\mathrm{OH}-\mathrm{PBacid}$.

$T l c$ of the methanol extract of feces showed the presence of more than 18 metabolites from the c-isomer. Each isolated metabolite was subjected to methylation with diazomethane. On reaction with diazomethane at room temperature overnight, the addition of a diazomethane molecule at the double bond occurred with some metabolites shown below (Table 5, compound $\mathrm{J}$ and $\mathrm{K}$ ).

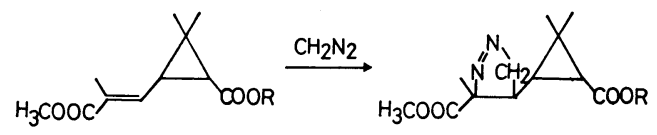

Therefore, to prevent formation of such addition products, methylation was carried out in methanol-ether at $0-4^{\circ} \mathrm{C}$ for $5 \mathrm{~min}$; this was repeated twice. Table 5 shows data on $\mathrm{nmr}$, ir and ms of 11 compounds.

Compound A: The nmr, ir and ms data of this compound were in good accord with those of the authentic, $\omega t$-alc-c-phenothrin.

Compound B: The nmr was similar to that of compound A except for the presence of one $3 \mathrm{H}$ singlet peak at $3.83 \mathrm{ppm}$ and absence of one aromatic $\mathrm{H}$ signal in the region of 6.70$7.50 \mathrm{ppm}$. The ms showed the molecular ion peak at $m / e 396$ and the base peak at $m / e 213$ which were 30 mass units larger than the corresponding peaks of compound A. These findings indicated the presence of one methoxy group in the alcohol moiety. In comparison with the $\mathrm{nmr}$ of $4^{\prime}-\mathrm{OCH}_{3}-\mathrm{PBacid}-\mathrm{Me}$, a methoxy group appeared to be present at the $4^{\prime}$-position. Therefore, compound $\mathrm{B}$ was identified as $4^{\prime}-\mathrm{OCH}_{3}-\omega t$-alc-c-phenothrin.

Compound $C$ : The $\mathrm{nmr}$ showed the absence of one methyl group of the isobutenyl group and the presence of one methoxy signal at $3.70 \mathrm{ppm}$. The ir indicated the presence of two carbonyl groups. In the ms, the base peak (m/e 183) due to a fragment of 3-phenoxybenzyl moiety ${ }^{2}$ was found. These findings indicated that one methyl of the isobutenyl group was converted to the methoxy carbonyl 
Table 5 Data on NMR, IR and MS of metabolites and methylated metabolites obtained from feces of rats receiving ${ }^{14} \mathrm{C}-c$-phenothrin.

\begin{tabular}{|c|c|c|c|}
\hline${ }^{14} \mathrm{C}-$ Compound & 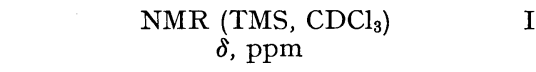 & $\begin{array}{l}\text { IR (chloroform) } \\
\mathrm{cm}^{-1}\end{array}$ & $\begin{array}{c}\mathrm{MS}(70 \mathrm{eV}) \\
m / e\end{array}$ \\
\hline A & $\begin{array}{l}1.20(\mathrm{~s}, 3 \mathrm{H}), 1.26(\mathrm{~s}, 3 \mathrm{H}), 1.76(\mathrm{~s}, 3 \mathrm{H}) \\
1.80-2.20(\mathrm{~m}, 2 \mathrm{H}), 4.03(\mathrm{~s}, 2 \mathrm{H}) \\
5.07(\mathrm{~s}, 2 \mathrm{H}), 5.70(\mathrm{~m}, 1 \mathrm{H}), 6.90-7.60(\mathrm{~m}, 8 \mathrm{H})\end{array}$ & $\begin{array}{l}3200-3700 \\
1720,1585 \\
1485\end{array}$ & $\begin{array}{l}366\left(\mathrm{M}^{+}\right) \\
183(\text { base peak) }\end{array}$ \\
\hline B & $\begin{array}{l}1.20(\mathrm{~s}, 3 \mathrm{H}), 1.25(\mathrm{~s}, 3 \mathrm{H}), 1.75(\mathrm{~s}, 3 \mathrm{H}) \\
1.75-2.20(\mathrm{~m}, 2 \mathrm{H}), 3.83(\mathrm{~s}, 3 \mathrm{H}), 4.05(\mathrm{~s}, 2 \mathrm{H}) \\
5.06(\mathrm{~s}, 2 \mathrm{H}), 5.70(\mathrm{~m}, 1 \mathrm{H}), 6.70-7.50(\mathrm{~m}, 8 \mathrm{H})\end{array}$ & $\begin{array}{l}3200-3700 \\
1720,1585 \\
1500\end{array}$ & $\begin{array}{l}396\left(\mathrm{M}^{+}\right) \\
213 \text { (base peak) }\end{array}$ \\
\hline $\begin{array}{c}\mathrm{C} \\
\mathrm{H}_{3} \mathrm{COO}\end{array}$ & $\begin{array}{l}1.26(\mathrm{~s}, 3 \mathrm{H}), 1.30(\mathrm{~s}, 3 \mathrm{H}), 1.93(\mathrm{~s}, 3 \mathrm{H}) \\
1.80-2.20(\mathrm{~m}, 2 \mathrm{H}), 3.73(\mathrm{~s}, 3 \mathrm{H}), 5.10(\mathrm{~s}, 2 \mathrm{H}) \\
6.80-7.50(\mathrm{~m}, 9 \mathrm{H})\end{array}$ & $\begin{array}{l}1720,1700 \\
1580,1480\end{array}$ & $\begin{array}{l}\cdot 394\left(\mathrm{M}^{+}\right) \\
183 \text { (base peak) }\end{array}$ \\
\hline $\begin{array}{l}D \\
\mathrm{H}_{3} \mathrm{COOC}\end{array}$ & $\begin{array}{l}1.26(\mathrm{~s}, 3 \mathrm{H}), 1.30(\mathrm{~s}, 3 \mathrm{H}), 1.92(\mathrm{~s}, 3 \mathrm{H}) \\
1.80-2.10(\mathrm{~m}, 2 \mathrm{H}), 3.73(\mathrm{~s}, 3 \mathrm{H}), 3.82(\mathrm{~s}, 3 \mathrm{H}) \\
5.08(\mathrm{~s}, 2 \mathrm{H}), 6.80-7.50(\mathrm{~m}, 9 \mathrm{H})\end{array}$ & $\begin{array}{l}1705,1720 \\
1590,1500\end{array}$ & $\begin{array}{l}424\left(\mathrm{M}^{+}\right) \\
213 \text { (base peak) }\end{array}$ \\
\hline $\begin{array}{c}\mathrm{E} \\
\mathrm{H}\end{array}$ & $\begin{array}{l}1.33(\mathrm{~s}, 3 \mathrm{H}), 1.93(\mathrm{~s}, 3 \mathrm{H}), 2.10-2.23(\mathrm{~m}, 2 \mathrm{H}) \\
3.56(\mathrm{~s}, 2 \mathrm{H}), 3.73(\mathrm{~s}, 3 \mathrm{H}), 5.10(\mathrm{~s}, 2 \mathrm{H}) \\
6.90-7.50(\mathrm{~m}, 10 \mathrm{H})\end{array}$ & $\begin{array}{l}3200-3650 \\
1705,1725 \\
1585,1490\end{array}$ & $\begin{array}{l}410\left(\mathrm{M}^{+}\right) \\
183 \text { (base peak) }\end{array}$ \\
\hline $\mathbf{F}$ & $\begin{array}{l}1.33(\mathrm{~s}, 3 \mathrm{H}), 1.92(\mathrm{~s}, 3 \mathrm{H}), 2.10-2.20(\mathrm{~m}, 2 \mathrm{H}) \\
3.56(\mathrm{~s}, 2 \mathrm{H}), 3.73(\mathrm{~s}, 3 \mathrm{H}), 5.08(\mathrm{~s}, 2 \mathrm{H}) \\
6.70-7.50(\mathrm{~m}, 9 \mathrm{H})\end{array}$ & $\begin{array}{l}3200-3700 \\
1700-1720 \\
1590,1500\end{array}$ & $\begin{array}{l}426\left(\mathrm{M}^{+}\right) \\
199 \text { (base peak) }\end{array}$ \\
\hline $\begin{array}{l}\text { G } \\
\mathrm{HO}\end{array}$ & $\begin{array}{l}1.18(\mathrm{~s}, 3 \mathrm{H}), 1.23(\mathrm{~s}, 3 \mathrm{H}), 1.83(\mathrm{~s}, 3 \mathrm{H}) \\
1.60-2.20(\mathrm{~m}, 2 \mathrm{H}), 4.19(\mathrm{~s}, 2 \mathrm{H}), 5.07(\mathrm{~s}, 2 \mathrm{H}) \\
5.56(\mathrm{~m}, 1 \mathrm{H}), 6.90-7.60(\mathrm{~m}, 9 \mathrm{H})\end{array}$ & $\begin{array}{l}3200-3700 \\
1720,1585 \\
1485\end{array}$ & $\begin{array}{l}366\left(\mathrm{M}^{+}\right) \\
183 \text { (base peak) }\end{array}$ \\
\hline $\begin{array}{l}\mathrm{H} \\
\mathrm{HOH}\end{array}$ & $\begin{array}{l}1.20(\mathrm{~s}, 3 \mathrm{H}), 1.24(\mathrm{~s}, 3 \mathrm{H}), 1.84(\mathrm{~s}, 3 \mathrm{H}) \\
1.60-2.20(\mathrm{~m}, 2 \mathrm{H}), 3.83(\mathrm{~s}, 3 \mathrm{H}), 4.20(\mathrm{~s}, 2 \mathrm{H}) \\
5.06(\mathrm{~s}, 2 \mathrm{H}), 5.56(\mathrm{~m}, 1 \mathrm{H}), 6.70-7.50(\mathrm{~m}, 8 \mathrm{H})\end{array}$ & $\begin{array}{l}3200-3700 \\
1720,1585 \\
1500\end{array}$ & $\begin{array}{l}396\left(\mathrm{M}^{+}\right) \\
213 \text { (base peak) }\end{array}$ \\
\hline $\begin{array}{c}\mathrm{I} \\
\mathrm{H}_{3} \mathrm{COOC}\end{array}$ & $\begin{array}{l}1.20(\mathrm{~s}, 3 \mathrm{H}), 1.24(\mathrm{~s}, 3 \mathrm{H}), 1.93(\mathrm{~s}, 3 \mathrm{H}) \\
1.60-1.90(\mathrm{~m}, 2 \mathrm{H}), 3.73(\mathrm{~s}, 3 \mathrm{H}), 3.83(\mathrm{~s}, 3 \mathrm{H}) \\
5.06(\mathrm{~s}, 2 \mathrm{H}), 6.36(\mathrm{~m}, 1 \mathrm{H}), 6.80-7.50(\mathrm{~m}, 8 \mathrm{H})\end{array}$ & $\begin{array}{l}1720,1700 \\
1585,1500\end{array}$ & $\begin{array}{l}424\left(\mathrm{M}^{+}\right) \\
213 \text { (base peak) }\end{array}$ \\
\hline$J$ & $\begin{array}{l}1.13(\mathrm{~s}, 3 \mathrm{H}), 1.16(\mathrm{~s}, 3 \mathrm{H}), 1.53(\mathrm{~s}, 3 \mathrm{H}) \\
1.50-1.80(\mathrm{~m}, 2 \mathrm{H}), 2.95(\mathrm{~m}, 1 \mathrm{H}), 3.73(\mathrm{~s}, 3 \mathrm{H}) \\
4.10-4.80(\mathrm{~m}, 2 \mathrm{H}), 5.10(\mathrm{~s}, 2 \mathrm{H}) \\
6.90-7.60(\mathrm{~m}, 9 \mathrm{H})\end{array}$ & $\begin{array}{l}1735,1720 \\
1584,1482\end{array}$ & $\begin{array}{l}436\left(\mathrm{M}^{+}\right) \\
183 \text { (base peak) }\end{array}$ \\
\hline 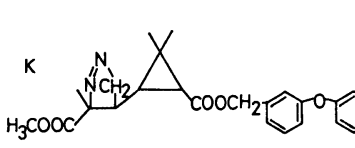 & $\begin{array}{l}1.13(\mathrm{~s}, 3 \mathrm{H}), 1.16(\mathrm{~s}, 3 \mathrm{H}), 1.53(\mathrm{~s}, 3 \mathrm{H}) \\
1.50-1.80(\mathrm{~m}, 2 \mathrm{H}), 2.95(\mathrm{~m}, 1 \mathrm{H}), 3.73(\mathrm{~s}, 3 \mathrm{H}) \\
3.83(\mathrm{~s}, 3 \mathrm{H}), 4.10-4.80(\mathrm{~m}, 2 \mathrm{H}), 5.06(\mathrm{~s}, 2 \mathrm{H}) \\
6.70-7.50(\mathrm{~m}, 8 \mathrm{H})\end{array}$ & $\begin{array}{l}1740,1720 \\
1585,1500\end{array}$ & $\begin{array}{l}466\left(\mathrm{M}^{+}\right) \\
213 \text { (base peak) }\end{array}$ \\
\hline
\end{tabular}

group. Ueda et al. ${ }^{7)}$ reported that the olefinic protons of $\omega t$ - and $\omega c$-acid-Me-c-chrysanthemic acids appear at 7.06 and $6.37 \mathrm{ppm}$, respectively. Based on the evidence, com- pound $\mathrm{C}$ was identified as $\omega t$-acid-Me- $-c-$ phenothrin.

Compound D: The nmr was similar to that of compound $\mathrm{C}$ except for the presence of one 
$3 \mathrm{H}$ singlet peak and the absence of one aromatic $\mathrm{H}$ signal. The $\mathrm{ms}$ showed the molecular ion peak at $m / e 424$ and the base peak at $m / e$ 213; these were each 30 mass units larger than those of compound C. These findings, as well as the comparison of the nmr or compound $\mathrm{B}$, indicated the presence of one methoxy carbonyl group at the $\omega t$ position of the isobutenyl group and one methyl group at the $4^{\prime}$-position of the alcohol moiety. Thus, compound D was identified as $4^{\prime}-\mathrm{OCH}_{3}-\omega t$ acid-Me-c-phenothrin.

Compound E: The ir showed a broad absorption peak due to the $\mathrm{OH}$ group and two peaks due to the carbonyl group. The $\mathrm{nmr}$ indicated the absence of one methyl of the gem-dimethyl group attached to the cyclopropane ring and the presence of a methylene group at $3.50 \mathrm{ppm}$. Unai et al. ${ }^{8}$ reported that the absorption peak due to a hydroxymethyl group $\left(\mathrm{CH}_{2} \mathrm{OH}\right)$ attached to the cyclopropane ring appears at about $3.50 \mathrm{ppm}$ with trans position and at about $3.90 \mathrm{ppm}$ with cis position relative to the carbonyl group. Thus, in compound $\mathrm{E}$ a hydroxy group is present at the trans methyl position of the gem-dimethyl group. Based on the evidence as well as the comparison with ir, $\mathrm{nmr}$ and $\mathrm{ms}$ of compound $\mathrm{C}$, compound $\mathrm{E}$ was identified as $\omega t$-acid-Me2-OH $(t)-c$-phenothrin.

Compound $F$ : The ms showed the molecular ion peak at $m / e 426$ which is 16 mass units higher than that of compound $\mathrm{E}$, and the base peak at m/e 199 due to 3-(hydroxyphenoxy) benzyl moiety. ${ }^{2)}$ The nmr showed the absence of one aromatic proton as compared with that of compound $\mathrm{E}$. Thus, another hydroxy group must have been present at the $4^{\prime}$-position of the alcohol moiety. Based on these finding, compound $\mathrm{E}$ was identified as $4^{\prime}-\mathrm{OH}-\omega t$-acid$\mathrm{Me}-2-\mathrm{OH}(t)-c-$ phenothrin.

Compound G: A broad peak at 3,200-3,700 $\mathrm{cm}^{-1}$ in the ir indicated the presence of an $\mathrm{OH}$ group. The ms showed the base peak at $m / e$ 183 due to 3-phenoxybenzyl moiety. ${ }^{2)}$ The nmr showed the absence of one methyl group of the isobutenyl group and the presence of one methylene group at $4.20 \mathrm{ppm}$. The latter appeared to be present at the $\omega c$-position of the isobutenyl group, since the peak due to the $\omega t$-hydroxy methylene group appears at 4.05 ppm. Thus, compound $G$ was identified as $\omega c$-alc-c-phenothrin.

Compound $H$ : The $\mathrm{nmr}$ was quite similar to that of compound $\mathrm{B}$ except for the appearance of one $2 \mathrm{H}$ singlet at $4.20 \mathrm{ppm}$, indicating a hydroxymethyl group at the $\omega c$-position of the isobutenyl group, as with compound G. Thus, compound $\mathrm{H}$ was identified as $4^{\prime}-\mathrm{OCH}_{3}-$ $\omega c$-alc-c-phenothrin.

Compound I: The $\mathrm{ms}$ and $\mathrm{nmr}$ of this compound were similar to those of compound D except for the appearance of one olefinic proton signal at $6.36 \mathrm{ppm}$ in the $\mathrm{nmr}$. Therefore, compound I appeared to have one methoxycarbonyl group at the $\omega c$-position of the isobutenyl group. ${ }^{7)}$ Based on the evidence, compound I was identified as $4^{\prime}-\mathrm{OCH}_{3}-\omega c$ acid-Me-c-phenothrin.

Compound $J$ : The $\mathrm{nmr}$ of this compound showed multiplet signals at $2.95 \mathrm{ppm}$ and $4.10-4.80 \mathrm{ppm}$, which were not found with compounds A-I. The ms showed the molecular ion at $m / e$ 436, 42 mass units larger than that of compound C. These findings indicated addition of one diazomethane molecule to the double bond of the isobutenyl group. Thus, the signals at $2.95 \mathrm{ppm}$ and $4.10-4.80 \mathrm{ppm}$ were assigned one proton at the $\mathrm{C}_{1}$ position of the isobutenyl group and one methylene group derived from diazomethane, respectively. From these findings, compound $\mathrm{J}$ was identified as the addition product of diazomethane to the double bond of compound C.

Compound $K$ : The nmr showed an additional singlet at $3.73 \mathrm{ppm}$ due to the $4^{\prime}$-methoxy group in comparison with those of compound $\mathrm{J}$. The molecular ion peak at $m / e 466$ is 30 mass units larger than that of compound $\mathrm{J}$. The evidence indicated the presence of an additional methoxy group at 4 '-position of compound $\mathrm{J}$. Thus, compound $\mathrm{K}$ was identified as the addition product of diazomethane to the double bond of compound D. The polar metabolites obtained from the feces of rats which had received an oral dose of $c$-phenothrin released $4^{\prime}-\mathrm{OH}-\mathrm{PBacid}, 4^{\prime}-\mathrm{OH}-\omega t$-acid$c-, 4^{\prime}-\mathrm{OH}-\omega c$-acid-c- and $4^{\prime}-\mathrm{OH}-\omega t$-acid-2$\mathrm{OH}(t)-c$-phenothrin as aglycones after sulfatase hydrolysis; these appeared to be excreted as sulfate conjugates. In addition, there were several polar metabolites which were not 
hydrolyzed by treatment with $\beta$-glucuronidase and/or sulfatase.

More than 13 fecal metabolites derived from the $t$-isomer were detected on $t l c$. The following metabolites were identified by $t l c$ cochromatography with authentic standards before and after methylation; $\omega t$-acid- $t$-phenothrin, $\quad \omega t$-alc- $t$-phenothrin, $\quad 4^{\prime}-\mathrm{OH}-\mathrm{PBacid}$, PBalc and PBacid. 4'-OH-PBacid was also found as an aglycone after sulfatase hydrolysis of the origin fraction.

\section{Amounts of Metabolites}

Tables 6 a) and b) show the amounts of metabolites excreted into the urine and feces during the 2 days following dermal and oral treatments. Major metabolites from the $t$ isomer were PBacid, 4'-OH-PBacid and their conjugates with glycine and sulfuric acid, which were mainly excreted into the urine and, to a minor extent, into the feces. On the other hand, most of the metabolites from the $c$-isomer retained the ester linkage and resulted from oxidations at the $4^{\prime}$-position of the alcohol moiety, at the cis and trans methyl of the isobutenyl moiety and at the trans methyl of the gem-dimethyl group attached to the cyclopropane ring of the acid moiety. These were largely excreted into the feces. Although hydrolysis products such as PBacid,

Table 6 Relative amounts of metabolites in the urine and feces 2 days after oral and dermal administration of ${ }^{14} \mathrm{C}-t$ - and $c$-phenothrin to rats.

a) Oral administration $(2 \mathrm{mg} / \mathrm{rat})$.

\begin{tabular}{|c|c|c|c|c|c|}
\hline \multirow{3}{*}{ Metabolite } & & \multicolumn{4}{|c|}{$\%$ of the administered radiocarbon } \\
\hline & & \multicolumn{2}{|c|}{$t$-Phen. } & \multicolumn{2}{|c|}{$c-$ Phen. } \\
\hline & & Urine & Feces & Urine & Feces \\
\hline \multicolumn{6}{|l|}{ Alcohol moiety } \\
\hline PBalc & & & 0.9 & & \\
\hline \multirow{3}{*}{ PBacid } & free & 10.0 & 1.3 & 2.1 & \\
\hline & glu. & 2.5 & & & \\
\hline & gly. & 2.7 & & 0.2 & \\
\hline \multirow[t]{3}{*}{$4^{\prime}-\mathrm{OH}-\mathrm{PBacid}$} & free & 5.6 & 4.9 & 0.9 & \\
\hline & sul. & 42.4 & 0.5 & 12.7 & 0.9 \\
\hline & glu. & 1.8 & & & \\
\hline $2^{\prime}-\mathrm{OH}-\mathrm{PBacid}$ & sul. & 1.0 & & 0.4 & \\
\hline \multicolumn{6}{|l|}{ Ester metabolites } \\
\hline$t$-Phen. & & & 1.2 & & \\
\hline$\omega t$-alc- $t$-Phen. $(\mathrm{O})$ & & & 0.4 & & \\
\hline$\omega t$-acid- $t$-Phen. (P) & & & 0.9 & & \\
\hline$c$-Phen. & & & & & 2.3 \\
\hline$\omega c$-alc-c-Phen. $(\mathrm{G})$ & & & & & 4.1 \\
\hline$\omega t$-alc-c-Phen. (A) & & & & & 3.1 \\
\hline $4^{\prime}-\mathrm{OH}-\omega c$-alc-c-Phen. $(\mathrm{H})$ & & & & & 2.4 \\
\hline $4^{\prime}-\mathrm{OH}-\omega t$-alc-c-Phen. (B) & & & & & 1.6 \\
\hline$\omega t$-acid-c-Phen. (C) & & & & & 7.9 \\
\hline \multirow[t]{2}{*}{$4^{\prime}-\mathrm{OH}-\omega c-$-acid-c-Phen. (I) } & free & & & & 2.4 \\
\hline & sul. & & & & 0.4 \\
\hline \multirow[t]{2}{*}{$4^{\prime}-\mathrm{OH}-\omega t$-acid- $-c-$ Phen. (D) } & free & & & & 3.9 \\
\hline & sul. & & & & 1.1 \\
\hline$\omega t$-acid-2-OH $(t)-c-$ Phen. $(\mathrm{E})$ & & & & & 3.7 \\
\hline \multicolumn{2}{|c|}{$4^{\prime}-\mathrm{OH}-\omega t$-acid-2-OH $(t)-c$-Phen. (F) } & & & & 13.0 \\
\hline & free & & & & \\
\hline & sul. & & & & 1.6 \\
\hline Unknown ${ }^{14} \mathrm{C}$ & & 3.2 & 9.1 & 1.1 & 18.2 \\
\hline Unextractable ${ }^{14} \mathrm{C}$ & & 4.8 & 2.6 & 2.6 & 6.1 \\
\hline Total ${ }^{14} \mathrm{C}$ & & 74.0 & 21.8 & 20.0 & 72.7 \\
\hline
\end{tabular}


b) Dermal (2 mg/rat).

\begin{tabular}{|c|c|c|c|c|c|c|c|c|c|}
\hline \multirow{4}{*}{\multicolumn{2}{|c|}{ Metabolite }} & \multicolumn{8}{|c|}{$\%$ of the administered radiocarbon } \\
\hline & & \multicolumn{4}{|c|}{$t$-Phen. } & \multicolumn{4}{|c|}{$c$-Phen. } \\
\hline & & \multicolumn{2}{|c|}{ Dust } & \multicolumn{2}{|c|}{ E.C. } & \multicolumn{2}{|c|}{ Dust } & \multicolumn{2}{|c|}{ E.C. } \\
\hline & & Urine & Feces & Urine & Feces & Urine & Feces & Urine & Feces \\
\hline \multicolumn{10}{|l|}{ Alcohol moiety } \\
\hline \multirow[t]{2}{*}{ PBacid } & free & 0.2 & $<0.1$ & 0.3 & 0.1 & 0.1 & & 0.2 & \\
\hline & gly. & $<0.1$ & & 0.1 & & & & & \\
\hline \multirow[t]{2}{*}{$4^{\prime}-\mathrm{OH}-\mathrm{PBacid}$} & free & 0.7 & 0.2 & 0.2 & 0.3 & 0.5 & & 1.2 & \\
\hline & sul. & 0.5 & & 1.6 & & $<0.1$ & & 0.2 & \\
\hline \multicolumn{10}{|l|}{ Ester metabolites } \\
\hline \multicolumn{2}{|l|}{$t$-Phen. } & & $<0.1$ & & & & & & \\
\hline \multicolumn{2}{|l|}{$c$-Phen. } & & & & & & $<0.1$ & & 0.1 \\
\hline \multicolumn{2}{|l|}{$\omega t$-acid-c-Phen. (C) } & & & & & & 0.1 & & 0.2 \\
\hline \multicolumn{2}{|l|}{$\omega c$-alc-c-Phen. (G) } & & & & & & $<0.1$ & & 0.1 \\
\hline \multicolumn{2}{|l|}{$\omega t$-alc-c-Phen. (A) } & & & & & & $<0.1$ & & $<0.1$ \\
\hline \multicolumn{2}{|c|}{$4^{\prime}-\mathrm{OH}-\omega c-$ alc $-c-$ Phen. $(\mathrm{H})$} & & & & & & $<0.1$ & & $<0.1$ \\
\hline \multicolumn{2}{|c|}{$4^{\prime}-\mathrm{OH}-\omega t-$ alc $-c-$ Phen. (B) } & & & & & & $<0.1$ & & $<0.1$ \\
\hline \multicolumn{2}{|c|}{$4^{\prime}-\mathrm{OH}-\omega c$-acid-c-Phen. (I) } & & & & & & $<0.1$ & & $<0.1$ \\
\hline \multicolumn{2}{|c|}{$4^{\prime}-\mathrm{OH}-\omega t-$ acid $-c-$ Phen. (D) } & & & & & & $<0.1$ & & 0.1 \\
\hline \multicolumn{2}{|c|}{$\omega t$-acid-2-OH $(t)-c-$ Phen. (E) } & & & & & & $<0.1$ & & 0.1 \\
\hline \multicolumn{2}{|c|}{$4^{\prime}-\mathrm{OH}-\omega t$-acid-2-OH $(t)-c-$ Phen. $(\mathrm{F})$} & & & & & & 0.1 & & 0.2 \\
\hline \multicolumn{2}{|l|}{ Unknown ${ }^{14} \mathrm{C}$} & 0.3 & 0.1 & 1.2 & 0.1 & $<0.1$ & 0.2 & 0.2 & 0.2 \\
\hline \multicolumn{2}{|l|}{ Aqueous ${ }^{14} \mathrm{C}$} & & $<0.1$ & & 0.1 & & 0.1 & & 0.1 \\
\hline \multicolumn{2}{|l|}{ Unextractable ${ }^{14} \mathrm{C}$} & $<0.1$ & $<0.1$ & 0.2 & 0.2 & 0.1 & 0.2 & 0.1 & 0.4 \\
\hline \multicolumn{2}{|l|}{ Total ${ }^{14} \mathrm{C}$} & 1.7 & 0.3 & 3.6 & 1.0 & 0.8 & 0.9 & 1.9 & 1.7 \\
\hline
\end{tabular}

glu.: glucuronide, gly.: glycine conjugate, sul.: sulfate.

4'-OH-PBacid and their conjugates derived from the $c$-isomer were excreted into the urine, their amounts were smaller compared with the $t$-isomer.

\section{DISCUSSION}

When dust and E.C. formulations of both $t$ - and $c$-isomers of phenothrin were dermally applied to rats, $86-94 \%$ and $78-85 \%$ of the dose was recovered from the treated sites with dust and E.C., respectively, and 3-7\% and $8-17 \%$ of the dose was recovered in the excreta with dust and E.C., respectively, during the 6 days after treatment. Total recovery was $89-98 \%$ of the dose with both formulations. Although small amounts of the radiocarbon were detected in the treated skin 6 days after dermal treatment, ${ }^{14} \mathrm{C}$ tissue residues were very low in other tissues analyzed. It seems that the radiocarbon absorbed through the skin was almost completely eliminated into the excreta during the
6 days, as with oral administration. Therefore, the amount of ${ }^{14} \mathrm{C}$ absorbed should approximately correspond to the amount of ${ }^{14} \mathrm{C}$ released into the excreta. The assumed ${ }^{14} \mathrm{C}$ absorption is $3-7 \%$ of the initial dose with dust and $8-17 \%$ with E.C. The comparison between the two formulations of isomers revealed a faster absorption with E.C. than with dust, whereas the half-life of ${ }^{14} \mathrm{C}$ was longer with E.C. than with dust. Such differences between E.C. and dust formulations are considered to be due to the following factor: the reagents used for E.C. formulation, such as xylene, Sorpol $3005 \mathrm{X}^{\circledR}$ and Span $80^{\circledR}$, may promote the absorption of phenothrin isomers into the skin tissue and therefore larger amounts of the chemicals are retained in this tissue. However, once entering the blood stream, phenothrin isomers were metabolized similarly to those of oral administration and the metabolites were almost completely eliminated in the excreta. 


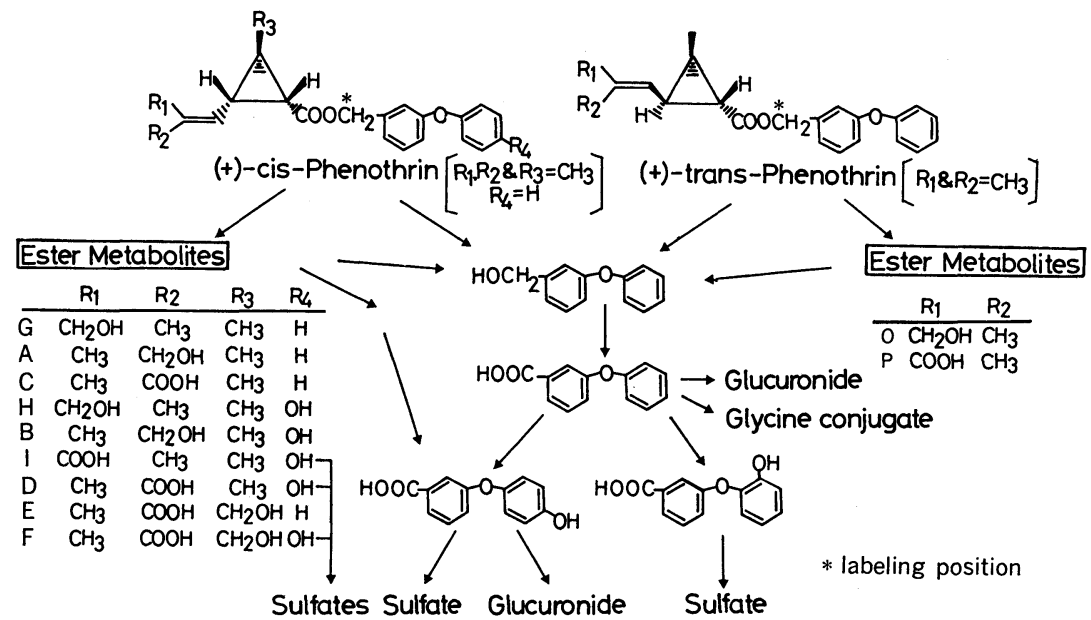

Fig. 3 Proposed metabolic pathways for phenothrin isomers in the rat.

Figure 3 shows the proposed metabolic pathways for phenothrin isomers in the rat. With the $c$-isomer, the major metabolic reaction was oxidation at the cis and trans methyl of the isobutenyl group and at the trans methyl of the gem-dimethyl group attached to the cyclopropane ring and at the $4^{\prime}$-position of the alcohol moiety. Hydroxylation at the 2'-position of the alcohol moiety occurred to a smaller extent. The cleavage of the ester linkage was also one of the major metabolic reactions. On the other hand, with the $t$ isomer, the main metabolic reaction was the ester cleavage which was 5 times greater than with the $c$-isomer. The hydroxylation at the 4 '-position of the alcohol moiety occurred with the $t$-isomer to the same degree as that with the $c$-isomer. Moreover, small amounts of the metabolites hydroxylated at the trans methyl of the isobutenyl group and at the $2^{\prime}-$ position of the alcohol moiety were obtained with the $t$-isomer. The significant hydrolysis metabolites, such as PBacid and $4^{\prime}-\mathrm{OH}-$ PBacid, derived from the $t$ - and $c$-isomers were further conjugated with glycine and sulfuric acid. Some of the ester metabolites from the $c$-isomer were also conjugated with sulfuric acid. In general, nearly the same metabolites were obtained with both oral and dermal treatments.

Miyamoto et al. ${ }^{1)}$ reported that $4^{\prime}-\mathrm{OH}-$ PBacid was the major metabolite, but $4^{\prime}-$ $\mathrm{OH}-\mathrm{PBacid}$ sulfate was below the limit of detection when the $t$-isomer was orally administered to rats at $200 \mathrm{mg} / \mathrm{kg}$. In the present study, 4'-OH-PBacid sulfate accounted for about $43 \%$ of the dose $(10 \mathrm{mg} / \mathrm{kg})$ by oral administration. This remarkable difference in the amount of the metabolite may be presumed to be due in part to the difference in the dose level.

Suzuki et $a l .{ }^{2)}$ indentified three ester metabolites derived from $c$-phenothrin, $\omega t$-acid$c$-phenothrin, $4^{\prime}-\mathrm{OH}-c$-phenothrin and $4^{\prime}-$ $\mathrm{OH}-\omega t$-acid-2-OH-c-phenothrin. In the present study, $4^{\prime}-\mathrm{OH}-c$-phenothrin was not detected, although the other two ester metabolites were found.

Oxidation at four methyl groups of the acid moiety occurred with the following preference. With the $c$-isomer, oxidation at the trans methyl of the isobutenyl group relative to the double bond occurred to a larger extent than at the cis methyl group. The trans methyl of the gem-dimethyl group relative to the carbonyl group with the $c$-isomer and the trans methyl of the isobutenyl group with the $t$ isomer were also oxidized. The preference of the oxidation sites in phenothrin isomers were in accord with the results of metabolism of allethrin and resmethrin, as reported by Yamamoto et al. ${ }^{9)}$ and Casida et al. ${ }^{10)}$ respectively.

\section{REFERENCES}

1) J. Miyamoto, T. Suzuki \& C. Nakae: Pestic. 
Biochem. Physiol. 4, 438 (1974)

2) T. Suzuki, N. Ohno \& J. Miyamoto: J. Pesticide Sci. 1, 151 (1976)

3) M. Hazue \& T. Kamata: unpublished observation

4) M. Matsui \& Y. Yamada: Agric. Biol. Chem. 27 (5), 373 (1963)

5) H. Ohkawa, H. Kaneko, T. Tsuji \& J. Miyamoto: J. Pesticide Sci. 4, 143 (1979)

6) K. Nambu, H. Ohkawa \& J. Miyamoto: $J$. Pesticide Sci. 5, 177 (1980)

7) K. Ueda \& M. Matsui: Agric. Biol. Chem. 34 (7), 1119 (1970)

8) T. Unai \& J. E. Casida: J. Agric. Food Chem. 25 (5), 979 (1977)

9) I. Yamamoto, E. C. Kimmel \& J. E. Casida: J. Agric. Food Chem. 17 (6), 1227 (1969)

10) J. E. Casida, K. Ueda, L. C. Gaughan, L. T. Jao \& D. M. Soderlund: Arch. Environ. Contam. Toxicol. 3, 491 (1976)

\section{要約}

\section{フェノスリンのラットにおける経皮吸収およ} び代謝

金子秀雄, 大川秀郎, 宮本純之 フェノスリン [3-phenoxybenzyl (士)-trans, (士)-cis- chrysanthemate] の (+)-trans 体および (+)-cis 体の ${ }^{14} \mathrm{C}$ 標識体（アルコール側ベンジル位標識）をおのおの 乳剂および粉剤にして雄ラットに $0.2 \mathrm{mg} /$ 匹 または 2 $\mathrm{mg} /$ 匹の割合で経皮処理した. 皮膚より体内に吸収され た ${ }^{14} \mathrm{C}$ は，処理 6 日後にほぼ完全に尿・兾に排泄され た. 推定 ${ }^{14} \mathrm{C}$ 吸収量は粉剤で処理量の $3-7 \%$, 乳剤で 8-17\% であった. 血中 ${ }^{14} \mathrm{C} レ$ レ゙ルの経時変化より, 粉 凨は乳刜に比べて吸収速度は 1/4 1/5 倍と遅く, 生物 学的半減期は $1 / 2 \sim 1 / 3$ 倍と短かった. 一方, 両異性体 を 1 回経口投与すると, ${ }^{14} \mathrm{C}$ はほぼ完全に排泄され, 経 皮処理と同様に，(+)-trans 体では尿に，(+)-cis 体 では䔬に多くの ${ }^{14} \mathrm{C}$ が排泄された。尿・䔬中代謝物は (+)-trans 体と (+)-cis 体で著しく異なっていた.すな わち, (+)-trans 体からの主代謝物は 3-phenoxybenzoic acid (遊離, グリシン抱合体) と 3-(4'-hydroxyphenoxy)benzoic acid (遊離, 硫酸抱合体) であり, (+)-cis 体からの主要代謝物はアルコール側の $4^{\prime}$ 位, 酸側のイ ソブテニル基の両メチル基および gem-ジメチルの一方 のメチル基（trans 位）が酸化を受けたエステル代謝物 であった. 経皮処理で認められた代謝物は経口投与によ っても検出されたことより, 経皮処理後ラット体内に吸 収されたフェノスリン異性体は経口投与の場合と同様に 速やかに代謝・排泄されると考えられる。 